Max-Planck-Institut für demografische Forschung

Max Planck Institute for Demographic Research

Konrad-Zuse-Strasse 1 - D-18057 Rostock - GERMANY

Tel +49 (0) 3812081 - 0; Fax +49 (0) 3812081 - 202;

http://www.demogr.mpg.de

MPIDR WORKING PAPER WP 2003-004

FEBRUARY 2003

\title{
Dissolution of unions in Europe: A comparative overview
}

Gunnar Andersson (andersson@ demogr.mpg.de))

This working paper has been approved for release by: Jan M. Hoem (hoem@demogr.mpg.de)

Head of the Laboratory of Contemporary European Fertility and Family Dynamics.

(c) Copyright is held by the authors.

Working papers of the Max Planck Institute for Demographic Research receive only limited review.

Views or opinions expressed in working papers are attributable to the authors and do not necessarily reflect those of the Institute. 


\author{
Max Planck Institute for Demographic Research, \\ Konrad-Zuse-Straße 1, \\ D-180 57 Rostock, Germany. \\ E-mail: andersson@demogr.mpg.de
}

GA, 7 February 2003

\title{
Dissolution of unions in Europe: A comparative overview
}

\author{
by Gunnar Andersson
}

\begin{abstract}
In this paper, we present a number of descriptive measures of couples' experience of union dissolution in a wide range of European countries. We use data from the last round of Fertility and Family Surveys in order to get a broad cross-country comparison of levels and basic patterns of union disruption in countries considered. We use corresponding data from the USA in order to find out to what extent patterns in Europe differ from those at the other side of the Atlantic. With a number of lifetable estimations we display levels of union dissolution of couples in different types of unions. Evidently, the picture looks different if one follows marriages from the date of marriage formation than if one follows any union from the date when a couple moves together. In addition, the stability of unions that start as cohabitation differs from the stability of unions that begin with a direct marriage. Our presentation reveals that unions in any European country are much more stable than unions in the US. The latter country stands out as an extreme case no matter what type of union we choose to study. Nevertheless, a high degree of variation also exists within Europe; a number of Catholic countries in Southern and Eastern Europe impress with particularly low levels of union dissolution.
\end{abstract}

Paper presented at the Conference on "Divorce in a Cross-National Perspective: A European Network", Florence, 14-15 November 2002. 


\section{Introduction}

Any sound investigation of a demographic phenomena must originate from some basic knowledge about its very general patterns: how common the demographic event of interest is, at what ages - or union durations - it typically occurs, and how such patterns in a country during a calendar period differ from those of other countries and periods. During the last three decades, we have witnessed an upsurge in studies on various aspects of family dynamics in developed countries. This is following an observed increase in the diversity that people tend to organize their family lives, manifested, among other things, in an increased instability of co-residential unions. A vast amount of research has been carried out in order to explain various aspects of union dynamics and to investigate consequences of observed changes.

The role of the present study is not to provide any further investigation of determinants of union dissolution. It is instead carried out in the belief that there is still a need for more and better basic description of the actual state of union dynamics in contemporary Europe. It is indeed important to first know exactly what there is to explain before one starts to look for explanations for various types of phenomena and before one turns to more sophisticated means of analysis. It is particularly important to get a better picture of various differences and similarities in family-demographic behavior between different countries in Europe. In some cases, the perception of a very volatile situation in the domains of family dynamics might turn out to be slightly exaggerated. The situation is not always as "dynamic" as one might think it is when reading research material stemming from the USA, for instance.

The aim of our study therefore is to provide an overview of existing patterns in survival of unions in a range of European countries, including countries at both sides of the former Iron Curtain. We account for the fact that in many countries people today often live together in unions without being married (see Prinz 1995, Toulemon 1997, Murphy 2000, and a special issue of International Journal of Law, Policy and the Family 2001 for a number of case studies on cohabitation in selected European countries). Consequently, the marital status of people is far from sufficient if one wants to get an accurate picture of their family status (Bumpass and Raley 1995). We demonstrate the importance of a distinction between different types of unions by depicting the survival patterns of different categories of families. 
Various related descriptions of union dynamics in developed countries have been presented elsewhere. Kiernan $(1999,2000,2001,2002)$ provides a number of cross-country comparisons of family dynamics in Europe, and Bumpass and HsienHen Lu (2000) give a related description for the United States. In the present study, we provide a coherent overview of the basic patterns of union dissolution in Europe by describing the dynamics in different types of unions with a standard set of descriptive measures.

We describe the processes of union dissolution by applying well-known lifetable techniques to available survey data. We believe that the use of life-table estimates on family-demographic topics might become more useful as standards in family-demographic description than they are today. In our presentation, we apply our descriptive measures to data from 15 of the countries that participated in the last round of Fertility and Family Surveys (FFS) conducted in Europe between 1989 and 1997. In addition, we use corresponding data from the US National Survey of Family Growth of 1995 in order to contrast patterns in Europe to those prevailing at the other side of the North Atlantic Ocean.

\section{Data and life-table methods}

The life table is an as old as important basic tool for the analysis of any survival pattern of a population. It can readily be linked to modern event-history analyses where explanatory variables are brought into the picture in order to explain existing patterns of decrements from the study population. While originally being used in studies of mortality, it can be used as well to describe any type of survival in a certain state. In our presentation, we make use of such applications by depicting the survival of individuals in various types of unions. For an in-depth technical description of the foundations of the life table, see any standard textbook in demography or statistics, like that of Preston et al. (2001). Hoem (2001) gives a brief overview of the topic.

The life tables in our presentation are all based on the notion of a synthetic cohort. They are derived from the information gathered from survey respondents pertaining to the six-year period immediately before each survey of interest. While a calculation of life tables for a real union cohort is a straightforward matter, it requires that one can follow the cohort of interest up to the highest duration limit of the 
tabulation, for example until 15 years after union formation. We prefer to be able to say something about the family-demographic behaviour during the most recent calendar period. For that purpose, we construct our life tables based on transition probabilities calculated from reported dissolutions of unions and recorded months of exposure to such events, by union duration, during the latest period for which we have data. (Each life table is based on the probabilities that a union at the duration of $\mathrm{x}$ years from union formation is dissolved by the exact duration $x+1$ years.) As any synthetic-cohort measure, our life tables give information on the demographic pattern that would arise if the calculated duration-specific transition probabilities prevail during a longer period of time.

Our tabulations depict the dynamics in any union regardless of union order. They are based on the pooled data from information as reported by female as well as by male respondents. Nevertheless, the information provided by women dominates the picture since all surveys include far more female than male respondents (Table 1). We use the relevant information for each union from the month of a reported unionformation event to an eventual dissolution or to a maximum union duration of exact 15 years. (We censor any observation at the possible but rare event of a reported partner's death.) The age structure of respondents makes it unfeasible to follow unions beyond a duration of 15 years. Since the FFS were directed only to women and men "at reproductive ages", data on unions at longer durations pertain to unions formed by respondents who were very young at the time of union formation. Such unions are likely to display very specific patterns of dissolution, and are thus not suitable to form the basis for a comparison that does not account explicitly for the age at union formation. (For an earlier version of our tabulations that includes unions up to a duration of 20 years, see Andersson and Philipov 2001, Tables 24-28.)

We have calculated life tables for the following countries: Sweden, Norway, Finland, France, the USA, Austria, Germany, Flanders (The Belgian FFS only covers the Flemish-speaking parts of the country), Italy, Spain, the Czech Republic, Hungary, Slovenia, Latvia, Lithuania, and Poland. East and West Germany are treated separately. For East Germany (referred to as the former GDR), we use the six-year term immediately before the political turnaround in November 1989 as our study period. We have not analyzed existing FFS data from Bulgaria and Portugal since they do not contain union histories of respondents and thus cannot be used for calculations like ours. 
Before calculating our life tables, we needed to perform a considerable amount of data cleaning. The raw data for Austria and Germany, just to mention one example, contained a large number of observations with missing dates of union formation and union dissolution of respondents so we had to exclude them from our calculations. Table 1 contains the total number of male and female respondents that, for each country, remain in our data set after our cleaning procedures. It also gives the age ranges of respondents and the calendar time of each survey. All respondents represent populations at reproductive ages but the upper age limit of respondents varies slightly between countries and the two sexes. Male respondents from Poland and the Czech Republic are excluded from our study since they are all partners to the female respondents and provide no unique information on their own. There are no men in the US study population either because no men were interviewed in the American survey. In our calculations, we have subsequently used all information that refers to the experience of women and men in unions at durations 0-15 years during the calendar periods upon which we base our synthetic cohorts. We have applied weights in our calculations of life-table estimates for France and the US since the sampling procedures in these countries were performed in a way that were dependent on the outcomes we want to study.

For further description of the data at hand and our system of life-table descriptions, see Andersson and Philipov (2002). Our presentation is based on their more extensive set of tabulations, covering a large number of life tables over men's, women's, and children's various experiences of different family-formation and family-dissolution events. (For a related overview with a summary of results concerning children's various experience of family-transformation events, see Andersson 2002). As a final remark, we want to point out the need for careful data validation in any project that uses standard files of FFS data (see Lesthaeghe 2000 for more comments on this issue). Despite our cleaning efforts, we have not been able to eliminate all inconsistencies in our data sets. We have also not been able to deal with all types of differences that exist in sampling procedures between countries. One important issue, for example, is to what extent immigrants tend to be represented in the various national data sets. For an evaluation of the Fertility and Family Surveys Project, see Festy and Prioux (2002). 


\section{Results}

In this section, we present our life-table estimates for persons in unions. For each country, we present the cumulative percentage of partners who have ever experienced a union-dissolution event at selected union durations. We report the cumulative percentage who would have experienced a dissolution of their union by the exact durations of $1,3,7$, and 15 years after union formation, had the observed transition probabilities prevailed. In each case, the possible event of a union dissolution refers to the moment when respondents reported that they stopped living together with their partner.

\section{3a) Marriage dissolution}

We begin with a presentation of marriage-dissolution patterns as they appear when we start our observation at the time of marriage formation (Table 2). Such an investigation includes all marriages, no matter if they are preceded by cohabitation or not. The tabulation reveals that in most European countries, between 20 and 30 percent of all marriages end in dissolution within a period of 15 years from the marriage formation. Sweden, the Czech Republic, and the two parts of Germany all display levels close to 30 percent of dissolved marriages. The highest level recorded for a European country otherwise is 35 percent, for Latvia. By contrast, a number of Catholic countries in Southern and Eastern Europe, namely Italy, Spain, Slovenia, and Poland, stand out as having particularly low levels of marriage disruption. No more than 10 percent of marriages in these countries get dissolved within 15 years. Finally, when we compare marriage-dissolution patterns in Europe to those prevailing in the USA, we find that the level of marriage disruption is nowhere as high as in the latter country: 42 percent of American marriages end in dissolution within 15 years from marriage formation. 


\section{3b) Union dissolution}

Next, we provide life-table estimates that give information on patterns in union dissolution, as they appear when we start the observation at union formation rather than at any reported marriage formation. By this procedure we include unions of all types, that is marriages as well as consensual unions. We disregard any information on subsequent transformations of a consensual union into a marriage, so that we simply follow each union from union formation until separation or censoring. Table 3 displays such patterns in union dissolution of partners in co-residential unions.

The inclusion of consensual unions in our description reveals that the levels of union dissolution are considerably higher than the levels of marriage dissolution as reported in Table 2. For countries in Europe, we often find that around 40 percent of all co-residential unions are dissolved within a period of 15 years from union formation. The highest level of union disruption in Europe is found for Sweden, with more than 50 percent of all unions being dissolved. At the other end of the scale, we find Poland where less than 10 percent of co-residential unions end in disruption, and Italy, Spain, Flanders, and Slovenia with final levels of 15-20 percent disrupted unions. Again, the USA is unique with its very elevated level of union dissolution: around 60 of all unions there end in disruption within 15 years. Many American unions are extremely short-lived: almost 20 percent of co-residential unions in the US dissolve already during their first year of existence.

\section{3c) Union dissolution by mode of entry into the union}

Next, we distinguish between patterns in union dissolution as they appear when we treat unions that began as a consensual union and unions that began as a direct marriage separately. Table 4 provides life tables that describe the survival of direct marriages, while Table 5 gives corresponding life tables of unions that began as a cohabitation (again by keep following each union of the latter type also after any transformation into a marriage).

Evidently, the rate of union dissolution is much higher for unions that began as a cohabitation than for unions whose respondents reported that it began as a direct marriage. In almost every country considered, the level of dissolved unions after 15 
years is twice as high, or more, for the former than for the latter type of union. Such an excess instability of unions beginning with cohabitation is evident in countries where this is the typical way to start a union (France, Austria, and the Nordic countries), as well as in countries where direct marriages dominate (Spain, Italy, Lithuania, Poland, Flanders, and Hungary), and in countries where both modes of entry into a union are common (the USA, the two parts of Germany, the Czech Republic, Slovenia, and Latvia). For background information on patterns in familyformation, see Andersson and Philipov (2002, Tables 4-5).

Table 4 reports that in the majority of European countries, around 15-25 percent of all direct marriages end in dissolution within 15 years. Levels of disruption are considerably lower, only 7-8 percent, for direct marriages in Italy, Spain, Slovenia, and Poland, but higher in Latvia, and, in particular, the USA. Close to 40 percent of direct marriages in the US end in disruption.

Table 5 confirms that also unions that have begun as a cohabitation are much less stable in the USA than they are in any European country considered: more than 70 percent of American unions of that kind dissolve within 15 years. Although such unions are also fairly unstable in Europe, for the majority of countries, the level of dissolved such unions lies in the range of 45-55 percent. Slovenia and Poland have the lowest level of dissolved unions of that kind: around 20 percent. Interestingly, unions in Italy and Spain who begin without a simultaneous marriage formation are not characterised by any relative degree of stability as compared to consensual unions in other countries.

\section{3d) Child-family dissolution}

In Table 6, finally, we report the cumulative percentage of unions of parents who experience the dissolution of their union after union formation and entry into parenthood. This table gives information on the disruption behaviour from yet another important date of the union-formation process. As a measure it might be a bit difficult to interpret when our purpose is that of cross-country comparison. In this case, the population under risk may either enter the risk population by childbirth or by union formation, whichever comes last, and is then followed until union disruption or censoring. Nevertheless, the tabulation is interesting not least because the motivation 
for many studies of union dissolution often is based on the concern for children involved. For a more complete description of family dynamics from the point of view of children, see Andersson (2002) and Heuveline et al. (2001).

Again, the relative ranking of countries according to their level of family stability looks very much like the one we are now familiar with. American unions that involve children are much less stable than child families in any European country in our study. In the USA, more than half of all unions of parents dissolve within a period of 15 years from the date of becoming a union of that kind. In Europe, Latvia and Sweden display the highest level of dissolution of unions of parents, with more than a third of such families being dissolved within 15 years. The highest levels of intact families of parents are found for Italy, Spain, Slovenia, and Poland, where just about 10 percent of parental unions end in family dissolution.

\section{Conclusions}

Our presentation has revealed both striking differences and strong similarities between countries when it concerns basic patterns of union dissolution. Evidently, the USA stands out as an extreme case with its very elevated level of union instability. No matter which type of union we study, we find that American unions more often end in dissolution than do co-residential unions in any of the 16 European countries we have considered. The differences in union stability between couples in the USA and couples in Europe are impressive but important variation also exists between countries in Europe. Our study covers the family-demographic situation in a relatively large number of countries from both sides of the former Iron Curtain. We do not find any systematic differences between countries in Eastern and Central Europe and countries in Western Europe but rather a variation between countries within each sphere of the continent. Some European countries are characterized by particularly stable family patterns. These countries are found in different areas of Europe but all have the trait in common of being strongly dominated by the Catholic confession. European countries with a higher degree of volatility in their family-demographic affairs are all characterized by a less influential role of religion in general and of Catholicism in particular. 
A further conclusion from our examination is that in any study of patterns in union dissolution it is very important to consider which definition of a union that is actually used. We have examined dissolution patterns in different types of unions, as defined according to what family-formation event that we chose to mark the onset of the union. Evidently, the level of stability differs between different kinds of unions. We could, for example, see that couples who begin their union as cohabitation are exposed to considerably higher disruption risks than couples who start living together only at marriage formation. Consequently, the general level of union disruption in a country is related to the prevalence of cohabitation there.

To conclude, we believe that our cross-country comparison has provided a lucid overview of the actual situation of the couple dynamics in Europe and the US and of existing differentials and similarities in patterns between countries. We found it particularly valuable to be able to include a number of East European countries in our study so that we could compare the situation in these countries with the situation in Western Europe. Our study of Eastern Europe mainly covers the period around or just after the transition from state socialism. For the future, it would be useful to derive comparable information from yet further countries - and time periods. It would be interesting to involve even more East European countries in our picture, in particular Russia and the various successor states of the former Soviet Union. In addition, it would be interesting to include Britain and other Anglo-Saxon countries into our cross-country comparison.

\section{Acknowledgments}

I am grateful to Dimiter Philipov for his cooperation in the production of the various life tables that have served as the basis for this paper. I am grateful for advice from Jan Hoem, Larry Bumpass, Ron Lesthaeghe, and Kathleen Kiernan on the setting up of our system of life tables (presented in Andersson and Philipov 2002). I thank the Advisory Group of the FFS programme of comparative research for its permission, granted under identification number 75 , to use the original FFS data on which this study is based. In addition, I am grateful to the Stockholm University Demography Unit for its permission to use a cleaned version of the Swedish FFS. 


\section{References}

Andersson, G. 2002. “Children's experience of family disruption and family formation: Evidence from 16 FFS countries". Demographic Research [Online] 7: 343-364. Available http://www.demographic-research.org/Volumes/Vol7/7.

Andersson, G., and Philipov, D., 2001. "Life-table representations of family dynamics in 16 countries". MPIDR Working Paper, WP 2001-024. Max Planck Institute for Demographic Research, Rostock.

Andersson, G., and Philipov, D., 2002. "Life-table representations of family dynamics in Sweden, Hungary, and 14 other FFS countries: A project of descriptions of demographic behavior". Demographic Research [Online] 7: 67-270. Available http://www.demographic-research.org/Volumes/Vol7/4.

Bumpass, L., and Hsien-Hen Lu, 2000. "Trends in cohabitation and implications for children's family contexts in the United States". Population Studies 54: 29-41.

Bumpass, L., and Raley, K., 1995. "Redefining single-parent families: Cohabitation and changing family reality". Demography 32: 97-109.

Festy, P., and Prioux, F., 2002. "An evaluation of the Fertility and Family Surveys Project". UNECE, United Nations, Geneva.

Heuveline, P., Timberlake, J., and Furstenberg, F., 2001. "An international comparison of children's experience of family structure". Paper presented at the IUSSP XXIV General Population Conference, Salvador, Brazil, 18-24 August 2001.

Hoem, J.M., 2001. "Life table", pp. 8832-8836 in Smelser, N., and Baltes, P., eds., International Encyclopedia of the Social \& Behavioral Sciences. Elsevier.

International Journal of Law, Policy and the Family, 2001. "Special issue: Unmarried cohabitation in Europe". Volume 15(1).

Kiernan, K., 1999. “Cohabitation in Western Europe”. Population Trends, No. 96: 2532.

Kiernan, K., 2000. "The state of European unions: An analysis of FFS data on partnership formation and dissolution". Paper presented at the FFS Flagship Conference, Brussels, 29-31 May 2000.

Kiernan, K., 2001. "The rise of cohabitation and childbearing outside marriage in Western Europe". International Journal of Law, Policy, and the Family 15: 121. 
Kiernan, K., 2002. "Cohabitation and divorce across nations and generations", in Chase-Lansdale, P.L., et al., eds., Potential for Change Across Lives and Generations: Multidisciplinary Perspectives. Cambridge University Press, forthcoming.

Lesthaeghe, R., 2000. "Fertility and partnership change: FFS contributions and requirements for the future". Paper presented at the FFS Flagship Conference, Brussels, 29-31 May 2000.

Murphy, M., 2000. "The evolution of cohabitation in Britain, 1960-95". Population Studies 54: 43-56.

Preston, S., Heuveline, P., and Guillot, M., 2001. Demography: Measuring and Modeling Population Processes. Blackwell, Oxford.

Prinz, C., 1995. Cohabiting, Married or Single: Portraying, Analyzing and Modeling New Living Arrangements in the Changing Societies of Europe. Ashgate Publishing Co, Brookfield, Vermont.

Toulemon, L., 1997. "Cohabitation is here to stay". Population: An English Selection 9: 11-56. 
Table 1: Number and ages of respondents, by country

\begin{tabular}{|c|c|c|c|c|c|c|}
\hline & Country & $\begin{array}{r}\text { Numbers: } \\
\text { women }\end{array}$ & men & $\begin{array}{c}\text { Ages: } \\
\text { women }\end{array}$ & men & $\begin{array}{r}\text { Time of } \\
\text { survey }\end{array}$ \\
\hline \multirow[t]{10}{*}{ "West" } & Sweden & 2986 & 1495 & $23-43$ & $28-43$ & $1992 / 93$ \\
\hline & Norway & 3969 & 1515 & $20-43$ & $28-43$ & $1988 / 89$ \\
\hline & Finland & 4040 & 1592 & $22-51$ & $25-49$ & $1989 / 90$ \\
\hline & France & 2930 & 1915 & $20-49$ & $20-49$ & 1994 \\
\hline & USA & 10510 & -- & $15-44$ & -- & 1995 \\
\hline & Austria & 4260 & 1428 & $20-54$ & $20-54$ & $1995 / 96$ \\
\hline & W Germany & 2743 & 1863 & $20-39$ & $20-39$ & 1992 \\
\hline & Flanders & 3143 & 2104 & $20-40$ & $20-40$ & $1991 / 92$ \\
\hline & Italy & 4745 & 1175 & $20-49$ & $20-49$ & $1995 / 96$ \\
\hline & Spain & 3981 & 1951 & $18-49$ & $18-49$ & $1994 / 95$ \\
\hline \multirow[t]{7}{*}{ "East" } & E Germany & 2810 & 1875 & $20-39$ & $20-39$ & 1992 \\
\hline & Hungary & 3498 & 1899 & $19-40$ & $20-44$ & $1992 / 93$ \\
\hline & Czech Rep & 1719 & -- & $15-44$ & -- & 1997 \\
\hline & Slovenia & 2761 & 1716 & $15-45$ & $15-45$ & $1994 / 95$ \\
\hline & Latvia & 2622 & 1338 & $18-49$ & $18-49$ & 1995 \\
\hline & Lithuania & 2924 & 1948 & $18-49$ & $18-49$ & $1994 / 95$ \\
\hline & Poland & 4165 & -- & $18-49$ & -- & 1991 \\
\hline
\end{tabular}


Table 2: Cumulative percent separated, by exact time since marriage formation

Country period $\underline{1 \text { year }} \underline{3 \text { years }} \underline{7 \text { years }} \underline{15 \text { years }}$

$\begin{array}{lccccc}\text { Sweden } & (1985-93) & 2 & 7 & 15 & 28 \\ \text { Norway } & (1983-89) & 1 & 5 & 12 & 22 \\ \text { Finland } & (1983-92) & 1 & 4 & 12 & 21 \\ \text { France } & (1988-94) & 1 & 4 & 11 & 20 \\ \text { USA } & (1989-95) & 5 & 15 & 29 & 42 \\ \text { Austria } & (1990-96) & 1 & 5 & 14 & 25 \\ \text { W Germany } & (1986-92) & 1 & 7 & 17 & 27 \\ \text { Flanders } & (1985-92) & 1 & 3 & 7 & 16 \\ \text { Italy } & (1990-95) & 0 & 2 & 4 & 8 \\ \text { Spain } & (1989-95) & 0 & 2 & 5 & 8 \\ \text { GDR } & (1984-89) & 1 & 5 & 16 & 28 \\ \text { Hungary } & (1988-93) & 2 & 6 & 13 & 21 \\ \text { Czech Rep } & (1992-97) & 2 & 8 & 16 & 28 \\ \text { Slovenia } & (1989-95) & 1 & 2 & 4 & 8 \\ \text { Latvia } & (1989-95) & 3 & 12 & 25 & 35 \\ \text { Lithuania } & (1989-95) & 1 & 4 & 13 & 21 \\ \text { Poland } & (1986-91) & 1 & 3 & 5 & 9\end{array}$

The estimates pertain to synthetic marriage cohorts experiencing the duration-specific transition rates prevailing six years prior to the survey date 
Table 3: Cumulative percent separated, by exact time since union formation, all unions

Country period $\underline{1 \text { year }} \underline{3 \text { years }} \underline{7 \text { years }} \underline{15 \text { years }}$

$\begin{array}{lccccc}\text { Sweden } & (1985-93) & 8 & 26 & 42 & 54 \\ \text { Norway } & (1983-89) & 7 & 20 & 31 & 40 \\ \text { Finland } & (1983-92) & 5 & 16 & 29 & 38 \\ \text { France } & (1988-94) & 7 & 18 & 31 & 41 \\ \text { USA } & (1989-95) & 19 & 36 & 49 & 61 \\ \text { Austria } & (1990-96) & 4 & 17 & 29 & 40 \\ \text { W Germany } & (1986-92) & 4 & 19 & 32 & 43 \\ \text { Flanders } & (1985-92) & 2 & 6 & 13 & 21 \\ \text { Italy } & (1990-95) & 4 & 7 & 10 & 14 \\ \text { Spain } & (1989-95) & 6 & 10 & 16 & 20 \\ \text { GDR } & (1984-89) & 5 & 14 & 26 & 37 \\ \text { Hungary } & (1988-93) & 5 & 14 & 22 & 30 \\ \text { Czech Rep } & (1992-97) & 5 & 13 & 23 & 33 \\ \text { Slovenia } & (1989-95) & 2 & 7 & 11 & 15 \\ \text { Latvia } & (1989-95) & 9 & 21 & 37 & 47 \\ \text { Lithuania } & (1989-95) & 3 & 8 & 18 & 26 \\ \text { Poland } & (1986-91) & 1 & 3 & 6 & 9\end{array}$

The estimates pertain to synthetic union cohorts experiencing the duration-specific transition rates prevailing six years prior to the survey date 
Table 4: Cumulative percent separated, by exact time since union formation, for unions begun as a marriage

Country period $\underline{1 \text { year }} \underline{3 \text { years }} \underline{7 \text { years }} \underline{15 \text { years }}$

$\begin{array}{lccccc}\text { Sweden } & (1985-93) & 3 & 5 & 8 & 20 \\ \text { Norway } & (1983-89) & 0 & 5 & 13 & 23 \\ \text { Finland } & (1983-92) & 1 & 5 & 12 & 21 \\ \text { France } & (1988-94) & 1 & 3 & 8 & 16 \\ \text { USA } & (1989-95) & 5 & 14 & 25 & 38 \\ \text { Austria } & (1990-96) & 2 & 7 & 16 & 26 \\ \text { W Germany } & (1986-92) & 0 & 7 & 16 & 24 \\ \text { Flanders } & (1985-92) & 1 & 2 & 7 & 15 \\ \text { Italy } & (1990-95) & 0 & 2 & 4 & 8 \\ \text { Spain } & (1989-95) & 0 & 1 & 4 & 7 \\ \text { GDR } & (1984-89) & 1 & 5 & 13 & 24 \\ \text { Hungary } & (1988-93) & 2 & 6 & 12 & 20 \\ \text { Czech Rep } & (1992-97) & 1 & 6 & 14 & 26 \\ \text { Slovenia } & (1989-95) & 1 & 1 & 3 & 7 \\ \text { Latvia } & (1989-95) & 2 & 10 & 24 & 35 \\ \text { Lithuania } & (1989-95) & 1 & 3 & 11 & 19 \\ \text { Poland } & (1986-91) & 1 & 2 & 5 & 8\end{array}$

The estimates pertain to synthetic union cohorts experiencing the duration-specific transition rates prevailing six years prior to the survey date 
Table 5: Cumulative percent separated, by exact time since union formation, for unions begun as a cohabitation (without censoring at marriage formation)

Country period $\underline{1 \text { year }} \underline{3 \text { years }} \underline{7 \text { years }} \underline{15 \text { years }}$

$\begin{array}{lccccc}\text { Sweden } & (1985-93) & 8 & 26 & 43 & 55 \\ \text { Norway } & (1983-89) & 8 & 22 & 34 & 45 \\ \text { Finland } & (1983-92) & 6 & 18 & 32 & 42 \\ \text { France } & (1988-94) & 8 & 20 & 36 & 48 \\ \text { USA } & (1989-95) & 25 & 46 & 60 & 72 \\ \text { Austria } & (1990-96) & 4 & 19 & 33 & 45 \\ \text { W Germany } & (1986-92) & 5 & 23 & 38 & 51 \\ \text { Flanders } & (1985-92) & 4 & 13 & 25 & 38 \\ \text { Italy } & (1990-95) & 18 & 29 & 36 & 43 \\ \text { Spain } & (1989-95) & 21 & 33 & 47 & 55 \\ \text { GDR } & (1984-89) & 8 & 21 & 37 & 49 \\ \text { Hungary } & (1988-93) & 10 & 26 & 40 & 53 \\ \text { Czech Rep } & (1992-97) & 7 & 19 & 29 & 39 \\ \text { Slovenia } & (1989-95) & 3 & 11 & 16 & 22 \\ \text { Latvia } & (1989-95) & 13 & 29 & 47 & 57 \\ \text { Lithuania } & (1989-95) & 8 & 20 & 41 & 55 \\ \text { Poland } & (1986-91) & 5 & 12 & 15 & 21\end{array}$

The estimates pertain to synthetic union cohorts experiencing the duration-specific transition rates prevailing six years prior to the survey date 
Table 6: Cumulative percent separated, by exact time since union formation/ entry into parenthood, unions of parents

Country period $\underline{1 \text { year }} \underline{3 \text { years }} \underline{7 \text { years }} \underline{15 \text { years }}$

$\begin{array}{lccccc}\text { Sweden } & (1985-93) & 4 & 12 & 24 & 36 \\ \text { Norway } & (1983-89) & 4 & 11 & 20 & 30 \\ \text { Finland } & (1983-92) & 2 & 8 & 17 & 26 \\ \text { France } & (1988-94) & 2 & 7 & 16 & 26 \\ \text { USA } & (1989-95) & 14 & 27 & 41 & 53 \\ \text { Austria } & (1990-96) & 2 & 8 & 18 & 28 \\ \text { W Germany } & (1986-92) & 2 & 8 & 17 & 30 \\ \text { Flanders } & (1985-92) & 1 & 3 & 7 & 16 \\ \text { Italy } & (1990-95) & 0 & 2 & 4 & 8 \\ \text { Spain } & (1989-95) & 2 & 4 & 7 & 10 \\ \text { GDR } & (1984-89) & 4 & 11 & 21 & 32 \\ \text { Hungary } & (1988-93) & 3 & 7 & 14 & 21 \\ \text { Czech Rep } & (1992-97) & 3 & 12 & 19 & 29 \\ \text { Slovenia } & (1989-95) & 1 & 3 & 6 & 11 \\ \text { Latvia } & (1989-95) & 5 & 16 & 28 & 38 \\ \text { Lithuania } & (1989-95) & 2 & 7 & 14 & 22 \\ \text { Poland } & (1986-91) & 1 & 3 & 4 & 8\end{array}$

The estimates pertain to synthetic union cohorts experiencing the duration-specific transition rates prevailing six years prior to the survey date 